\title{
The Impact of Internal Corporate Social Responsibility on Job Satisfaction in Jordanian Pharmaceutical Companies
}

\author{
Bader Obeidat ${ }^{1}$, Sura Altheeb ${ }^{1} \&$ Ra'ed Masa'deh ${ }^{2}$ \\ ${ }^{1}$ Department of Business Management, School of Business, The University of Jordan, Amman, Jordan \\ ${ }^{2}$ Department of Management Information Systems, School of Business, The University of Jordan, Amman, \\ Jordan \\ Correspondence: Bader Obeidat, Department of Business Management, School of Business, The University of \\ Jordan, Amman, Jordan. E-mail: b.obeidat@ju.edu.jo
}

Received: June 13, 2018 Accepted: September 20, 2018 Online Published: October 29, 2018

doi:10.5539/mas.v12n11p105 URL: https://doi.org/10.5539/mas.v12n11p105

\begin{abstract}
This study investigates the impact of internal corporate social responsibility on job satisfaction in Jordanian pharmaceutical companies. Quantitative research design and regression analysis were applied on a total of 302 valid returns that were obtained in a questionnaire based survey from 14 pharmaceutical companies among employees, supervisors and managers. The results showed that internal corporate social responsibility was significantly related to job satisfaction and three of its dimensions, namely working conditions, work life balance and empowerment contributed significantly to job satisfaction, whereas employment stability and skills development had no contribution. This study implies that Jordanian pharmaceutical companies have to try their best to promote and facilitate internal corporate social responsibility among their employees in an effort to improve their job satisfaction, which will eventually yield positive results for the company as a whole. In light of these results, the research presented many recommendations for future research; the most important ones were the application of this study in other sectors, cultures, and countries, and using of multi method for collecting data.
\end{abstract}

Keywords: internal corporate social responsibility, employee job satisfaction, pharmaceutical industry, Jordan

\section{Introduction}

Back in the 1880s and during the introduction of Business Administration and Social Science stage of industrialization, the discussion about the social responsibility of companies was broadly spread. Most of the advocates for social responsibility claimed that all companies should introduce some forms of social ethics and responsibility. Some advocates argued that taking social responsibility would weaken the economic growth due to the associated deterioration in competition between companies. Since the late 1880 s the discussion about the social responsibility has progressed and most of companies started to adopt more concepts about the corporate social responsibility (Carlsson \& Åkerstöm 2008).

Several attributes can be considered as a social responsibility, which are related to customers, employees, and society (Al Azmi et al., 2012; Obeidat et al., 2017). Hence, all organizations are trying to invest in different attributes of social responsibility to increase the employees' job satisfaction (Suher, Bir \& Yapar, 2017). Corporate social responsibility (CSR) is divided into external and internal (Tamm et al., 2010). On the one hand, the external responsibility is all about the corporate involving its employees in some types of social project. On the other hand, internal CSR involve human resources practices such as training and labor participation (Calveras, 2013), which affect the well-being of the employees (Tamm et al., 2010). The external CSR affect external stakeholders observed by consumers, whereas the internal one have a social impact on internal stakeholders namely employees (Elfenbein et al., 2012). Both types are important and they complement each other, both are needed and linked to products and services quality (Calveras, 2013).

Working on several attributes of social obligations and responsibility to be part of the human resources strategies have turned out to be the most important, durable and effective way to keep the employees satisfied (Yousaf, 2016). All companies that support CSR gain employees' engagement and satisfaction, attract new talents, retain customers and enhance the company's brands. Most of the published studies were concerned with the corporate 
social responsibility study only in its external dimensions that focus on taking the responsibilities toward the environment and social wellbeing and ignoring the internal dimensions that affect the wellbeing of the employees (Aguilera et al., 2007; Mory et al., 2015). Therefore, many companies in different industries are trying to increase their knowledge and involvement about the works related to the internal social responsibility, and the pharmaceutical industry in Jordan is no exception to that.

\subsection{Research Problem}

Recently, a high competition among the pharmaceutical companies in Jordan has been noticed. Hence, the companies need to ensure that all of their assets are being used and managed very well in order to stay in the market and be successful. Due to the rapid change in the Pharmaceutical industry, the human resources and the effectiveness of their productivity have become the most crucial factor to maintain a good performance and ensure the success of the company. The productivity of employees and the effectiveness of their work is linked to the level of their satisfaction with their job and organization. Raising the job satisfaction is a big mission that each company should achieve by fulfilling the company's internal responsibility towards its employees (Parvin \& Nurul, 2011)

Although there are many previous studies that indicated the relation between corporate social responsibility and job satisfaction in pharmaceutical industry, these studies focused only on the external dimensions while ignoring the internal ones (Aguilera et al., 2007; Mory et al., 2015). Indeed, employees are considered the most valuable asset in the organization. The success or failure of the organization completely depends on them, that is why job satisfaction is a very important topic that most of the companies should focus on. Therefore, this study will focus on the internal dimensions of the social corporate responsibility in order to identify its impact on the job satisfaction in the pharmaceutical companies in Jordan.

\subsection{Research Significance}

The pharmaceutical sector in Jordan is greatly contributing in the GDP and supporting the economy of Jordan. Jordanian Association of Pharmaceuticals is always working on providing a sustainable and accessible pharmaceutical services and products locally and internationally. The association has been offering a continuous effort in developing this sector by raising the awareness about the importance of this industry and participating in conferences related to the sector in order to carry the experiences in manufacturing and management area and implement them in the companies in Jordan.

The human resources are always considered as the lead resources to take any industry to flourish and improvement. Hence, the comfort and satisfaction of the employees in any company should be maintained to a high level of quality in order for them to provide their maximum capacity of production. The comfort and satisfaction of employees can be maintained when the company works on providing all kind of internal and external social responsibilities, which will create an adequate environment to work in.

The study could provide a comprehensive understanding about the impact of internal social responsibility on employees' job satisfaction in pharmaceutical companies in Jordan, which will give them a clear insight on how to increase the satisfaction of the employees in order to enhance the effectiveness of their productivity. Hence, achieve a better performance and strengthen the companies' position in the market. The results of this research could be in an interest for further research in Jordan and other similar countries.

\subsection{Pharmaceutical Sector in Jordan}

The Hashemite Kingdom of Jordan is considered one of the most advanced countries in the Middle East region and worldwide in the sector of Pharmaceutical industries. This sector has started to improve and grow very enormously since 1962 and still showing continuous great development these days. The pharmaceutical industry in Jordan is considered a story of success and excellence, it is a well-developed industry since 50 years, and it has a high reputation and presents a good image locally and worldwide. Due to the good manufacturing practices (GMP), high quality and affordable prices, this sector considered as a major contributor to the national economy, a round $80 \%$ of its production power is exported to more than 70 countries around the world including USA and Europe. The contribution of the pharmaceutical products is accounting for about $10 \%$ of total Jordanian exports (Jordanian Association of Pharmaceutical Manufacturers, 2017). Jordanian Association of Pharmaceutical Manufacturers (JAPM) was established in 1996 and it considers as the head representative association for the most of the pharmaceutical companies in Jordan.

The mission of JAPM is to support, develop and upgrade the Jordanian pharmaceutical industry to world-class standards through technology transfer, industry integration and the implementation of current 'Good Manufacturing Practice' (GMP) (Jordanian Association of Pharmaceutical Manufacturers, 2017). There are 14 
pharmaceutical companies in Jordan, which gives Jordan the privilege to pioneer among countries in the Arab world. The first pharmaceutical factory was founded in 1962 and since then the industry has been growing significantly. The pharmaceutical companies in Jordan have been equipped with advanced machineries, technologies, experiences and knowledge in order to provide the best environment and place for a good manufacturing process to achieve high quality products. Table 1 present a summary of the pharmaceutical companies in Jordan established since 1957.

Table 1. Pharmaceutical companies operating in Jordan

\begin{tabular}{ll}
\hline No. & Established Year \\
\hline Dar Al-Dawa Development and Investment Co. (DAD) & 1957 \\
The Arab Pharmaceutical Manufacturing Co. Ltd. (APM) & 1962 \\
Hikma Pharmaceuticals (HIKMA) & 1977 \\
The Jordanian Pharmaceutical Manufacturing Co. PLC & 1978 \\
The Arab Center for Pharmaceutical and Chemical (ACPC) & 1983 \\
Amman Pharmaceutical Industries & 1989 \\
The United Pharmaceutical Manufacturing Co. Ltd. (UPM) & 1989 \\
RAM Pharmaceutical Industries Co. Ltd (RAM) & 1992 \\
Hayat Pharmaceutical Industry Co. Ltd. (HPI) & 1993 \\
Middle East Pharmaceutical Manufacturing Co. Ltd. (MIDPHARMA) & 1993 \\
Pharma International (NTER) & 1994 \\
Jordan Sweden Medical and Sterilization Co. (JOSWE) & 1996 \\
Jordan River Pharmaceutical Industries Co. (JoRiver) & 1999 \\
TQ PHARMA & 2007 \\
\hline
\end{tabular}

Source: Members of the Jordanian Association Pharmaceutical Manufacturers (JAPM)

\section{Theoretical Framework and Research Hypotheses}

The aim of this research is to identify the impact of internal corporate social responsibility on job satisfaction in pharmaceutical companies in Jordan. To define the dependent and independent variables and develop the theoretical framework for this study, extensive studies in the literature were reviewed. As a result, the internal corporate social responsibility was found to be the independent variable and the job satisfaction as the dependent variable.

Several studies have found that a positive relationship exists between internal corporate social responsibility and employee's satisfaction (eg. Aguilera et al., 2007; Heslin \& Ochoa, 2008; Yousaf et al., 2016). Therefore, internal corporate social responsibility is assumed to have a positive relationship with employees satisfaction based on the findings of these researchers and others. This relationship has a great effect on the turnover rate, recruitment, retention, loyalty and commitment of the employees toward their job which is reflected on the performance and the productivity rate of the employees (Santoso, 2014; Yousaf et al., 2016). We noticed that there is a strong direct relationship between the dimensions of internal corporate social responsibility chosen in this study (working environment, skills development, work life balance, employment stability and empowerment) and the employee satisfaction.

Thang \& Fassin (2017) mentioned in their study that there is a positive relationship between working conditions, training and development and work life balance and the employees' satisfaction. While Mory et al. (2015) concluded in their study that there is a strong positive effect from working condition, training and development, work life balance, employment stability and empowerment on job satisfaction (Shibeika, 2015; Yousaf et al., 2016) stated that there is a relationship between working condition and training and development and the employee satisfaction. Cavazotte \& Chang (2016) study the relationship between training and development and work life balance and its effect on job satisfaction and the result show that there is a positive relationship between them. Calveras (2013) referred the job satisfaction to training and development and employment stability. Spreitzer (1995) focus on the positive relationship between empowerment and employee satisfaction. According to what have been found in previous studies, the framework shown in figure 1 comprising the dependent, independent variables, and their dimensions, which will be considered as the theoretical framework for this research. 


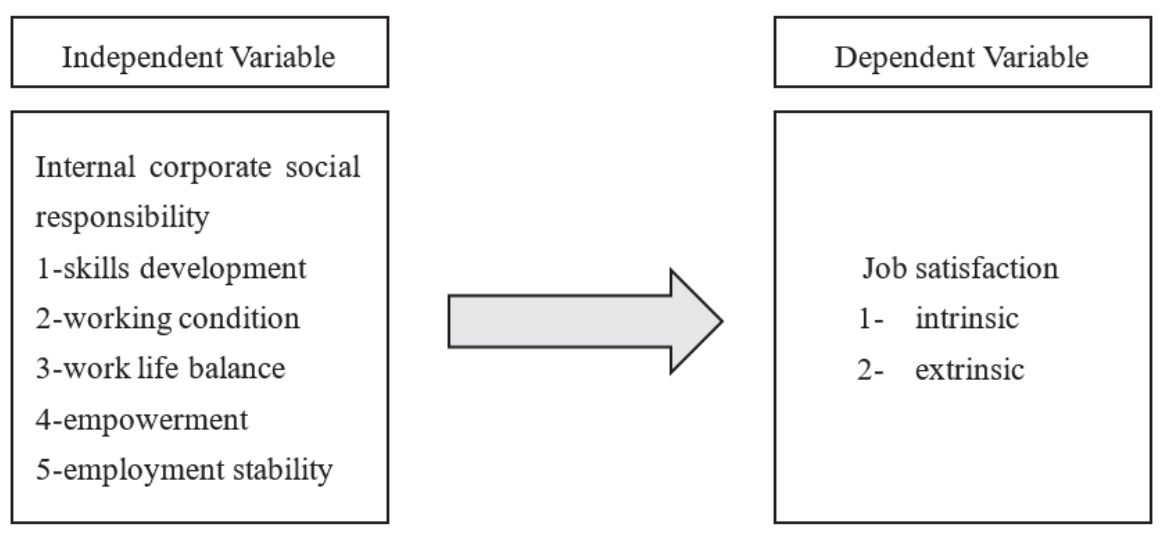

Figure 1. The research proposed model for variables and their relationship developed by the researchers based on the study conducted by Mory et al. (2015)

\subsection{Operational Definition of the Variables}

The operationalization of variables is important as it provide an easy way to measure the concepts that usually cannot be measured directlywhich might relate to feeling, opinions, or feelings. The items selected to measure the two concepts (internal corporate social responsibility and employee satisfaction) were primarily derived and adapted from existing literature of prior studies.

\subsubsection{Independent Variable}

Internal corporate social responsibility (I-CSR) refers to stakeholder approach focus on satisfying the interest of the stakeholders that can be affected by the operational activities (Nasrullah et al., 2014). It can be anything done inside the organization to improve the life of the employees which affect their productivity and directly affect the profitability (Pietersz, 2011). I-CSR was operationalized using the following dimensions: working conditions, work life balance, employment stability, skills development and empowerment. Working conditions relates to issues of health and safety at work place which is required to be safe in order to reduce accidents that have a negative impact on employees' health and work intensity. Skills development can be defined as to which extent the employees' skills are promoted inside the organization (Masa'deh et al., 2015; Mory et al., 2015). It concerns the issues related to the education and vocational training (Bayley, 2015). Employment stability refers to which extent the company provide and secure stable jobs for its employees, it must provide comfort, support, security and stability for the employees regarding their jobs (Mory et al., 2015). Work life balance is achieved when the employees feel that their work life and personal life are being used to the maximum level and with minimal conflict between them. It can be guaranteed by creating an internal culture that minimize negative norms and designing policies that support this issues such as flexible work hours, paid maternity leave, leave and time off and vacations. Empowerment can be summarized as delegation of decision and responsibilities from higher organization levels to lower ones and sharing information with individuals at the lower level by giving them support, power and needed resources (Spreitzer, 1995).

These dimensions of independent variables were chosen to be investigated by choosing 18 different measurements to reflect them. Table 2 shows a summary of the independent variable (Internal social corporate responsibility) dimensions and its measurements.

Table 2. Internal social corporate responsibility measurement

\begin{tabular}{lll}
\hline $\begin{array}{l}\text { Internal social corporate responsibility } \\
\text { Dimensions }\end{array}$ & Measurements & $\begin{array}{l}\text { Number of questions in the } \\
\text { questionnaires }\end{array}$ \\
\hline Working & The safety of workers is a high priority with Questions 5,6,7,8. \\
Conditions & management where I work. & \\
& All new employees undergo proper medical check-up. \\
& The campaign on health issues, safety and healthy \\
& lifestyle are frequent. \\
& I have good medical insurance for me and my family.
\end{tabular}


Skills

Development

Employment

Stability

Work-life Balance
Training is provided during change of jobs or transfer to a new job.

Training is provided on the use of new equipment or technology in my workplace.

Refresh for information about work is always done.

Training for new skills needed in the work is always done.

My job provides steady employment.

As employees, do you think of quitting from your current work?

The chances for promotion are good.

The chance to do different things from time to time.

No conflict between my own life and work.

The organization takes initiatives to manage work life of its employees.

I have enough information to get the job done.

I have the opportunity to develop my own special abilities.

I am given a lot of freedom to decide how to do my own work.

I supervise others at work as a part of my job.
Questions 1, 2, 3, 4 .

Questions 9, 10, 11.

Questions 12, 13, 14 .

Questions 15, 16, 17, 18.

\subsubsection{Dependent Variable}

Job satisfaction is defined as the series of action and attitudes arise from emotional state of the employees towards their job experience and work environment. Moreover, job satisfaction reflects the feelings of the employees during doing their duties and responsibilities (Ardakani et al. 2013). Employee satisfaction was operationalized using intrinsic job satisfaction and extrinsic job satisfaction.

Intrinsic job satisfaction refers to employees feeling about their job. Many factors can contribute in evaluating the intrinsic satisfaction such as moral values, creativity, achievement, power and independence (Abdallah et al., 2017). Extrinsic job satisfaction reflects the satisfaction of employees regarding the work tasks or the work itself (Abdallah et al., 2017). It can be achieved by providing a positive supervision behavior, pay satisfied salaries and availability of employee benefits and incentives. These two dimensions of dependent variables were chosen to be investigated by choosing 10 different measurements to reflect them. Table 3 includes the dimensions and measurements of the dependent variables (Job Satisfaction).

Table 3. Job satisfaction measurements

\begin{tabular}{|c|c|c|c|}
\hline $\begin{array}{l}\text { Job Satisfaction } \\
\text { Dimensions }\end{array}$ & & Measurements & $\begin{array}{l}\text { Number of questions in the } \\
\text { questionnaires }\end{array}$ \\
\hline $\begin{array}{l}\text { Intrinsic } \\
\text { Satisfaction }\end{array}$ & Job & $\begin{array}{l}\text { The chance to tell people what to do. } \\
\text { The freedom to use my judgment. } \\
\text { I feel like a part of the family at my } \\
\text { organization. } \\
\text { I really feel as if these organization problems are } \\
\text { my own. } \\
\text { The chance to be somebody in the community. }\end{array}$ & Questions 19, 20, 21, 22, 23 \\
\hline $\begin{array}{l}\text { Extrinsic } \\
\text { Satisfaction }\end{array}$ & Job & $\begin{array}{l}\text { The chances for advancement in this job } \\
\text { The way company polices is put into practices. } \\
\text { The working conditions } \\
\text { Good way for my supervisor to handle his/her } \\
\text { workers. } \\
\text { My salary and workload are suitable. }\end{array}$ & Questions 24, 25, 26, 27, 28. \\
\hline
\end{tabular}




\subsection{Research Hypotheses}

\subsubsection{The Main Null Hypothesis of the Current Research}

H0.1: There is No statistically significant impact $(\alpha \leq 0.05)$ of internal corporate social responsibility on job satisfaction, in pharmaceutical companies in Jordan.

\subsubsection{Sub-null Hypotheses}

H0.1.1: There is no statistically significant impact of skills development on job satisfaction.

H0.1.2: There is no statistically significant impact of working condition on job satisfaction.

H0.1.3: There is no statistically significant impact of employment stability on job satisfaction.

H0.1.4: There is no statistically significant impact of work life balance on job satisfaction.

H0.1.5: there is no statistically significant impact of empowerment on job satisfaction.

\section{Research Methodology}

\subsection{Data Collection Design}

Secondary data was extracted from previous studies in the literature; all studies were sourced out from different international published journal and the University of Jordan e-library to identify previous literature and authors who contributed to theories and old studies. Also, a survey questionnaire was used since the research seeks to examine the impact of internal corporate social responsibility on job satisfaction in pharmaceutical companies in Jordan. Initially, a set of internal social corporate responsibility's dimensions were selected to be measured using different attributes. The researchers designed the questionnaire survey using the online survey tool (Google Forms). The questionnaire contained 18 different items to measure the internal corporate social responsibility (I-CSR) adapted in Jordan's pharmaceutical companies, these measurements were taken from the study conducted by Mory et al. (2015). On the other hand, 10 different items were adapted from the study conducted by Abdallah et al. (2017) in order to use them to measure employee satisfaction. All items are measured using a five point rating scale (Likert scale) from one: 'strongly disagree', two: 'Disagree', three: 'moderately agree', four: 'agree', five: 'strongly agree'.

\subsection{Sampling \& Selection of the Population}

The purpose of this study is to determine the impact between internal corporate social responsibility and employee satisfaction in pharmaceutical companies in Jordan. 14 pharmaceutical companies were invited and encouraged to participate in this research. The researchers contacted with employees in these pharmaceutical companies in Jordan and they welcomed and accepted to participate in this study to provide some information about their experience in their companies and help in data collection. The population of this study consists of all the employees working in Jordanian pharmaceutical companies. It has been reported that the number of employees working in pharmaceutical companies in Jordan was 5414 (Jordanian Association Pharmaceutical Manufacturers, 2017).

After selecting the population, the next step is to select a sample from this population for the study. Convenience sampling was adopted to obtain the needed information quickly and efficiently, due to the hard accessibility and security issues in the pharmaceutical sector which prevent the researchers from gaining access to employees. The entire population of the study is 5414 individuals. In order to get real reflecting results a sample size of 356 employees were used. A questionnaire is used as the major instrument of the study. 400 online questionnaires were sent to employees at all levels and departments in the companies. A total number of questionnaires received back was 315 , accordingly the response rate was 79 , which is relatively acceptable. 13 were excluded for illogical answers for most of the questions. Therefore, the remaining 302 responses and were valid to be used for the statistical analysis.

\subsection{Research Validity \& Reliability}

Content validity was employed in this study to check the validity of the study instrument. It is important to test the questions before using it to collect data. Presenting and piloting can help identify questions that do not make sense to participants, or problems with the questions that might lead to biased answers. A pilot test was conducted. After finishing designing the questionnaire, it was distribute to a small number of group and let them complete the survey the same way that it will be completed in the actual project, and taking into consideration every comment from them. As a result, one question was deleted from employment stability questions, which was 'my job provides job security', because most of the respondents think that it was similar to another question in the same section. Minor changes were done in the questionnaire in the way the questions were written just to 
make it more clearly for all the participants. In addition, the time taken to complete the survey by the respondents in the pilot study was recorded and the average was calculated. It took 6 minutes to complete the questionnaire, which considered a reasonable time to spend answering questions. Also, we use Cronbach Alpha technique to test the reliability, the value need to be above (0.7) (Pallant, 2005).

Table 4. Cronbach alpha for main variables

\begin{tabular}{ll}
\hline Variable & Cronbach Alpha \\
\hline Internal corporate social responsibility & 0.839 \\
Job Satisfaction & 0.911 \\
\hline
\end{tabular}

Table 5. Cronbach alpha for the dimensions

\begin{tabular}{ll}
\hline Dimension & Cronbach's Alpha \\
\hline Skills development & 0.730 \\
Working conditions & 0.695 \\
Employment stability & 0.620 \\
Work life balance & 0.801 \\
Empowerment & 0.719 \\
Intrinsic job satisfaction & 0.651 \\
Extrinsic job satisfaction & 0.642 \\
\hline
\end{tabular}

\section{Data Analysis and Discussion}

\subsection{Demographic profile of the respondents}

The data collected through the questionnaire distributed to the employees were analyzed using Statistical Package for Social Science version 21.0. The demographic characteristics of the respondents can be shown in table 6 .

Table 6. The respondents' profile

\begin{tabular}{lll}
\hline Respondent's characteristics & Frequency & Percentages \\
\hline Gender & 190 & \\
\hline Male & 112 & 62.90 \\
Female & 302 & 100 \\
\hline Total & & \\
\hline Age & 144 & 47.70 \\
\hline Less than 25 years & 86 & 28.50 \\
25 to less than 30 years & 46 & 15.20 \\
30 to less than 35 years & 26 & 8.60 \\
35 and above & 302 & 100 \\
\hline Total & & \\
\hline Job Title & 107 & 35.40 \\
\hline Medical rep. & 10 & 3.30 \\
Product specialist & 18 & 6.00 \\
Regulatory affairs officers & 15 & 5.00 \\
Quality assurance & 17 & 5.60 \\
Registration & 67 & 22.20 \\
Managers & 4 & 1.30 \\
Logistics & 13 & 4.30 \\
HR & 11 & 3.60 \\
Others & 40 & 13.20 \\
Chemical and mechanical engineers & 302 & 100 \\
\hline Total & & \\
\hline Years of Experience & & \\
\hline & & \\
\hline
\end{tabular}




\begin{tabular}{lll}
\hline Less than 5 years & 144 & 47.70 \\
5 to less than 10 years & 86 & 28.50 \\
10 to less than 15 years & 46 & 15.20 \\
15 years and above & 26 & 8.60 \\
\hline Total & 302 & 100 \\
\hline
\end{tabular}

Demographic profile of the study sample presented in table 6 shows the distribution of the participants in terms of gender, age, educational level, job position, and years of experience. As it can be seen in the above table, the demographic profile of the respondents shows that $62.9 \%$ of them were male and $37.10 \%$ were female. This suggests that the majority of employees working in the pharmaceutical companies are males; however, this should not necessarily mean that male workers are preferable. As it can be seen, there is no distinction exists between males and females when it comes to employment in the pharmaceutical industries in Jordan as the work is considered appropriate for both and the employees are chosen based on their qualifications in terms of education, experience during the recruitment process.

With regards to age, the majority of employees working in the pharmaceutical sector $47.70 \%$ belong to the age group of less than 25 years, followed by $28.50 \%$ belonging to the age group of 25 to less than 30 years, $15.20 \%$ between 30 and less than 35 , and the least were (8.60\%) 35 and above. The results showed that the there is a fair mix of age groups in pharmaceutical industries, indicating that the questionnaires were distributed to all employees and that these findings are consistent with other respondents' characteristics.

In terms of experience, $47.70 \%$ of the respondents with less than 5 years of experience, followed by $28.50 \% 5$ to less than 10 years of experience. It is clear that the years of experience are related to the respondent's age groups, in which $47.7 \%$ of respondents aged less than 25 years old, have less than 5 years of experience. Finally, with regards to position held by the employees who participated in the study, this study focuses on all job title inside the organization in order to give accurate information.

\subsection{Descriptive Statistics}

First, it is necessary to show the equation that used for categorizing the levels of importance into three levels (high, medium, low) as below according to the following equation:

Level of Importance $($ Category length $)=($ Upper limit - Lower limit $) /$ Number of levels.

Where: Upper limit $=5$, Lower limit $=1$ and Number of levels $=3$

Level of Importance (Category length) $=(5-1) / 3=4 / 3=1.33$

Therefore, the category length becomes as below:

Table 7. Interpretation criteria for the variables' mean

\begin{tabular}{lll}
\hline Low level of importance & Medium level of importance & High level of importance \\
\hline $1-2.33$ & $2.34-3.67$ & $3.68-5$ \\
\hline
\end{tabular}

The classification of the descriptive analysis of all variables was based on those presented in table 7. A brief overview of the means and standard deviations of the study variables is presented in table 8 and 9.

Table 8. Mean average score and standard deviation of research variables

\begin{tabular}{lcll}
\hline Variable & Mean & Standard Deviation & The Mean Level \\
\hline Independent Variable & & & \\
\hline Internal corporate social responsibility & 3.24 & 0.588 & Medium \\
Working condition & 3.56 & 0.893 & Medium \\
Skills development & 3.60 & 0.809 & Medium \\
Employment stability & 2.77 & 0.579 & Medium \\
Work life balance & 2.7 & 0.864 & Medium \\
Empowerment & 3.2 & 0.588 & Medium \\
\hline Dependent Variable & & & \\
\hline Job satisfaction & 3.35 & 0.759 & Medium \\
Intrinsic job satisfaction & 3.4 & 0.85 & Medium \\
Extrinsic job satisfaction & 3.3 & 0.77 & Medium \\
\hline
\end{tabular}


The findings shown in the previous table indicate that the study main variables are relatively important for the respondents in the pharmaceutical industries in Jordan. More in details, the internal corporate social responsibility has a mean of 3.24 with a standard deviation of 0.588 . This indicates that the majority of participants' generally has positive attitudes concerning the statements in I-CSR. Regarding the employee job satisfaction, the mean of job satisfaction is 3.35 which is considered highly important relative to the statements of job satisfaction. In addition, the standard deviation of job satisfaction is 0.759 .

Table 9. Mean average score and standard deviation for the research variables

\begin{tabular}{|c|c|c|c|}
\hline No. & Item & Mean & $\begin{array}{l}\text { Standard } \\
\text { Deviation }\end{array}$ \\
\hline \multicolumn{4}{|c|}{ Skills development } \\
\hline 1 & $\begin{array}{l}\text { Training is provided during change of jobs or transfer to a } \\
\text { new job. }\end{array}$ & 3.73 & 1.024 \\
\hline 2 & $\begin{array}{l}\text { Training is provided on the use of new equipment or } \\
\text { technology in my workplace. }\end{array}$ & 3.68 & 0.994 \\
\hline 3 & Refresh for information about work is always done. & 3.69 & 0.966 \\
\hline 4 & Training for new skills needed in the work is always done. & 3.67 & 1.036 \\
\hline \multicolumn{4}{|c|}{ Working conditions } \\
\hline 5 & $\begin{array}{l}\text { The safety of workers is a high priority with management } \\
\text { where I work. }\end{array}$ & 3.90 & 1.080 \\
\hline 6 & All new employees undergo proper medical checkup. & 3.42 & 1.371 \\
\hline 7 & $\begin{array}{l}\text { The campaign on health issues, safety and healthy lifestyle } \\
\text { are frequent. }\end{array}$ & 2.79 & 1.115 \\
\hline 8 & I have good medical insurance for me and my family. & 4.14 & 1.031 \\
\hline \multicolumn{4}{|c|}{ Employment stability } \\
\hline 9 & The way my job provides steady employment. & 3.48 & 1.024 \\
\hline 10 & $\begin{array}{l}\text { As employees, do you think of quitting from your current } \\
\text { work? }\end{array}$ & 2.14 & 1.176 \\
\hline 11 & The chances for promotion are good. & 2.72 & 0.981 \\
\hline \multicolumn{4}{|c|}{ Work life balance } \\
\hline 12 & The chance to do different things from time to time. & 2.70 & 1.074 \\
\hline 13 & No conflict between my own life and work. & 3.06 & 1.052 \\
\hline 14 & $\begin{array}{l}\text { The organization takes initiatives to manage work life of its } \\
\text { employees. }\end{array}$ & 2.34 & 1.038 \\
\hline \multicolumn{4}{|c|}{ Empowerment } \\
\hline 15 & I have enough information to get the job done. & 3.50 & 0.929 \\
\hline 16 & I have the opportunity to develop my own special abilities. & 3.38 & 1.016 \\
\hline 17 & $\begin{array}{l}\text { I am given a lot of freedom to decide how to do my own } \\
\text { work. }\end{array}$ & 3.19 & 1.096 \\
\hline 18 & I supervise others at work as a part of my job. & 2.91 & 1.299 \\
\hline \multicolumn{4}{|c|}{ Intrinsic job satisfaction } \\
\hline 19 & The chance to tell people what to do. & 3.34 & 1.030 \\
\hline 20 & The freedom to use my judgment. & 3.28 & 1.026 \\
\hline 21 & I feel like a part of the family at my organization. & 3.65 & 1.032 \\
\hline 22 & I really feel as if this organization problem is my own. & 3.40 & 1.187 \\
\hline 23 & The chance to be somebody in the community. & 3.34 & 1.075 \\
\hline \multicolumn{4}{|c|}{ Extrinsic job satisfaction } \\
\hline 24 & The chances for advancement in this job & 3.09 & 0.915 \\
\hline 25 & The way company polices are put into practices. & 3.17 & 1.080 \\
\hline 26 & The working conditions & 3.54 & 0.883 \\
\hline 27 & Good way for my supervisor to handle his/her workers. & 3.56 & 1.091 \\
\hline 28 & My salary and workload are suitable. & 3.15 & 1.108 \\
\hline
\end{tabular}




\subsection{Multi-Collinearity Diagnostics}

In order to discover multi-collinearity in this study, both indicators of variance inflation factor (VIF) and tolerance were used. Myers (1990) suggested that the VIF should be near to (1) and not greater than (10). Another measure to be taken into consideration is the tolerance statistic, which is the reciprocal of the VIF (1/VIF). According to Sekaran \& Bougie (2013) a common cutoff value is a tolerance value of 0.10 , and a VIF value of 10 , which is what was used in this study.

Table 10. Multi-collinearity diagnostics for the study model

\begin{tabular}{lll}
\hline Variables & Tolerance & VIF \\
\hline Working conditions & 0.668 & 1.497 \\
Skills development & 0.559 & 1.788 \\
Employment stability & 0.776 & 1.288 \\
Work life balance & 0.529 & 1.892 \\
Empowerment & 0.513 & 1.950 \\
\hline
\end{tabular}

Since the values of the variance of inflation (VIF) are lower than (10) and the value of tolerance is higher than $(0.1)$ therefore there is no collinearity problem in the study regression models. Accordingly, the researchers can perform the inferential statistics for the study hypotheses.

\subsection{Regression Analysis}

In order to test the research hypotheses, multiple regression was used. Internal corporate social responsibility (working conditions, skills development, employment stability, empowerment and work life balance) was entered as the independent variable and job satisfaction was entered as the dependent variable in order to obtain the results of the regression analysis from SPSS. The results of testing the first main hypothesis are demonstrated in the following table.

Table 11. Multiple regression for the sub hypothesis

\begin{tabular}{llllllll}
\hline & $\mathrm{R}$ & $\mathrm{R}^{2}$ & Adjusted $^{2}$ & F-value & Standardized Beta & t-value & Sig. \\
\hline Working conditions & 0.82 & 0.67 & 0.66 & $119.06^{* * *}$ & 0.23 & 5.57 & $0.000^{* * *}$ \\
Skills developments & & & & & 0.05 & 1.07 & 0.286 \\
Employment stability & & & & & 0.04 & 1.15 & 0.252 \\
Work-life balance & & & & 0.20 & 4.24 & $0.000^{* * *}$ \\
Empowerment & & & & & 0.51 & 10.79 & $0.000^{* * *}$ \\
\hline
\end{tabular}

The correlation coefficient $\mathrm{R}=0.82$ indicates that there is a positive correlation between I-CSR and job satisfaction as mentioned above. This proves that the independent variables and dependent variable change in the same direction. R square, coefficient of determination, provides information regarding the goodness of fit of the regression model (Sekaran \& Bougie, 2013). In other words, it represents the percentage of variance in the dependent variable that is explained by the variation in the independent variable (Sekaran \& Bougie, 2013). The value of $\mathrm{R}^{2}=0.67$ indicates the amount of variations in job satisfaction that is accounted by the fitted model and has been explained by I-CSR. The adjusted $\mathrm{R}^{2}$ indicates the generalizability of the model. It allows generalizing the results taken from the respondents to the whole population. It is noticed that the value of the adjusted $\mathrm{R}^{2}=$ 0.66 is very close to the value of $R^{2}=0.67$. If the adjusted $R^{2}$ is excluded from $R^{2}$ the value will be $(0.67-0.66=0.01)$. This amount of reduction means that if the whole population participates in the study and the model has been fitted then, there will be $1 \%$ reduction in the variance of the outcome.

Results from the coefficients table, the $t$ and sig. (which is known as p-value) values, give a rough indication of the contribution of each predictor variable. A large absolute $t$-value and small $p$-value suggests that the predictor variable does contribute to the criterion variable. The results show that all the dimensions of emotional intelligence are significant contributors to job performance ( $p$-value $<0.05)$ except for skills development and employment stability (p-value $>0.05$ ). Furthermore, the standardized beta coefficient is a measure of the contribution of the predictor variable to the criterion variable (Pallant, 2005). A large value indicates that a unit change in this predictor variable has a large effect on the criterion variable. In this study empowerment has the most contribution to job satisfaction with a $\beta$ of 0.51 which indicates that it is a strong predictor of job 
satisfaction. Based on the results obtained from the multiple regression the following decisions can be made regarding the sub hypotheses of the main hypothesis.

Table 12. The result of testing the first null hypotheses and related sub hypotheses

\begin{tabular}{|c|c|}
\hline $\begin{array}{l}\text { There is no statistically significant impact of internal corporate social } \\
\text { responsibility on job satisfaction. }\end{array}$ & Rejected \\
\hline $\begin{array}{l}\text { There is no statistically significant impact of working conditions on job } \\
\text { satisfaction. }\end{array}$ & Rejected \\
\hline $\begin{array}{l}\text { There is no statistically significant impact of empowerment on job } \\
\text { satisfaction. }\end{array}$ & Rejected \\
\hline $\begin{array}{l}\text { There is no statistically significant impact of skills development on job } \\
\text { satisfaction. }\end{array}$ & Accepted \\
\hline $\begin{array}{l}\text { There is no statistically significant impact of work life balance on job } \\
\text { satisfaction. }\end{array}$ & Rejected \\
\hline $\begin{array}{l}\text { There is no statistically significant impact of employment stability on } \\
\text { job satisfaction. }\end{array}$ & Accepted \\
\hline
\end{tabular}

\section{Discussion, Conclusion and Recommendations}

Based on the fact that there are limited published studies concerning the internal corporate social responsibility (I-CSR) in pharmaceutical companies in Jordan, this research aimed to investigate the impact of internal corporate social responsibility on job satisfaction in pharmaceutical companies.

\subsection{Review of Main Findings}

The aim of this study was to investigate the impact of internal corporate social responsibility (I-CSR) on job satisfaction in pharmaceutical companies in Jordan. This research is different from other ones, as it focuses on the internal corporate social responsibility because there are many studies that focused on the external responsibility. Based on Mory et al. (2015) model, five dimensions were used to measure I-CSR which are working conditions, skills development, work life balance, employment stability and empowerment. Job satisfaction was measured using two different dimensions: the extrinsic and intrinsic.

Also, a model was developed and the hypotheses were set. A simple random sample was used, and the questionnaire was distributed to different pharmaceutical companies in Jordan. As a result, 302 responses were used to perform the analysis. The questionnaire was designed to measure the effect of I-CSR on job satisfaction, the questionnaire showed satisfactory results in terms of validity and reliability. Content validity was showed and approved by doing a pilot study. The reliability was tested using Cronbach's alpha coefficients. All the values obtained exceeded the recommended threshold of 0.60 , indicating good internal consistency among the items within each dimension for each variable.

Data analyses were carried out using SPSS. A multiple regression was performed. In addition, the decision to reject or accept the null hypotheses depended on p-value, where p-value was lower than 0.05 the null hypothesis should be rejected and the alternative should be accepted. The demographic profile of the respondents for this study showed that the majority of the participants were males with a percent of $62.9 \%$ with ages less than 25 years old, educational level varied among participants where most of them had either a bachelor degree or a master's degree, have less than 5 years of experience. The descriptive statistics showed the mean and standard deviation for each item, dimension, and variable used in the questionnaire. The results indicated that the respondents had positive attitudes towards internal corporate social responsibility and job satisfaction.

The results of multiple regression analysis for the main hypothesis showed that I-CSR and job satisfaction were significantly and positively related. Internal corporate social responsibility significantly predicted job satisfaction, Beta $=0.782$. The multiple regression coefficients show the following: working conditions have a significant impact on job satisfaction, $B$ eta $=0.228, \mathrm{t}=5.566, \mathrm{p}<0.001$. Work-life balance significant impact on job satisfaction, $B e t a=0.195, \mathrm{t}=4.240, \mathrm{p}<0.001$. Empowerment significant impact on job satisfaction, Beta $=0.505, \mathrm{t}=$ $10.790, \mathrm{p}<0.001$. On the other hand, the skills development, Beta $=0.048, \mathrm{t}=1.069, \mathrm{p}=0.286$, and employment 
stability, Beta $=0.044, \mathrm{t}=1.148, \mathrm{p}=0.252$ had no significant effect on job satisfaction.

Regarding the result of this study, it has been found that working conditions has a significant impact on job satisfaction. Indeed this finding is supported by such scholar (e.g. Thang \& Fassin, 2017; Mory et al., 2015; Yousaf et al., 2016). Health and safety at work is considered as a legal compliance leads to competitive advantage and world class business performance. As for the work life balance, it has been found that work life balance has a remarkable effect in enhancing job satisfaction. This finding is supported the conclusion of such researchers (e.g. Mory et al., 2015; Cavazotte \& Chang, 2016; Thang \& Fassin (2017).

Also, it can be noted that empowerment can be useful in enhancing job satisfaction. This finding was in line with scholars as (Spreitzer, 1995; Mory et al., 2015). Employees' empowerment strengthens the self efficacy and confidence to accomplish the tasks (Ugboro \& Obeng, 2000). It also increases the self esteem of individuals, which is reflected positively on the performance of the employees and the organization (Spreitzer, 1995).

\subsection{Contribution of the Research}

This study was conducted in Jordan unlike other studies that were done in different countries under specific settings and environment. Hence, other studies do not suit every country because there is a difference between the behaviors of employees in each country depending on culture and companies' rules and work place (e.g. Shannak \& Obeidat, 2012). Therefore, this study aimed to understand the relation between internal corporate social responsibility and job satisfaction since no published research discus this topic in this particular industry in Jordan.

Most of previous researchers have focused in their studies only on CSR in general without investigating the external and internal sides of it. As well, this research highlights the critical impact of internal corporate social responsibility (I-CSR) on job satisfaction. The researchers hope to provide key recommendations for pharmaceutical companies in term of I-CSR topic that will help in enhancing job satisfaction for employees and improve the productivity and position of pharmaceutical industry in the market of Jordan. The result of this research could be in an interest for further research in Jordan and other similar countries.

\subsection{Recommendations for the Pharmaceutical Companies in Jordan}

In order to raise the awareness concerning the importance of I-CSR and that could be done through sharing experiences between companies and analyzing the current practices being used. Companies should maintain their employees motivated by giving those benefits and incentives when they accomplish the required work and tasks. Also, managers should involve the employees in early stages in regards to the decisions they make and might affect them in the work (see e.g. AlHarrasi \& AL-Lozi, 2015; AlHarrasi et al., 2016; AL-Syaidh et al., 2016; Darawsheh et al., 2016; Alkandari et al., 2017; Khalayleh et al., 2017; Abualoush et al., 2018a, 2018b; Al-dalahmeh et al., 2018; Masa'deh, et al., 2018). Companies should organize events that engage all employees together to create a healthy environment and culture between them

\subsection{Limitations of the Research and Future Recommendations}

All studies regardless of the accuracy of performing them hold some limitations. These limitations must be used when evaluating the results of the study and should be mentioned to provide guidance for future research and to fill the gaps. First, the data collection was only based on questionnaire survey and every method has shortfalls and might cause biases. The respondents may have overemphasized the positive aspects of I-CSR and job satisfaction. It is recommended to use multi method of data collection to overcome this bias such as conducting interviews with employees to get more detailed overview about this issue. Second, this study chooses the pharmaceutical sector as the main area to conduct the research. It is recommended to conduct this research in different sectors as the banking, telecommunication, higher education or other sector that would benefit from the results of the study. Another limitation is the number of respondents who participated in answering the questionnaire. The sample for the study based on the design must be 356 but the actual sample used in the analysis was 302. In addition to illogical responses that were neglected. For future studies, a larger sample size is preferred in order to decrease the error and get a higher quality of answers to the questions.

Also, researchers called for more research on the enabling factors of applying electronic services (e.g. Masa'deh, et al., 2008, 2013a, 2013b; Karajeh \& Maqableh, 2014; Maqableh \& Karajeh, 2014; Al-Dmour et al., 2015; Almajali \& Maqableh, 2015; Kateb et al., 2015; Maqableh et al., 2015; Masa'deh, 2016; Tarhini et al., 2015; 2016, 2017a, 2017b; Almajali \& Al-Dmour, 2016; Almajali et al., 2016; Alenezi et al., 2017; Aldmour et al., 2017; Khwaldeh et al., 2017; Mikkawi \&Al-Lozi, 2017; Obeidat et al., 2017; Yassien \& Mufleh, 2017; Tarhini et al., 2018; Al-Dmour et al., 2019), hence, future research is vital to explore in new electronic venues the relationship between internal corporate social responsibility on job satisfaction. 


\section{References}

Abdallah, A., Obeidat, B., Aqqad, N., Al Janini, M., \& Dahiyat, S. (2017). An integrated model of job involvement, job satisfaction and organizational commitment: A structural analysis in Jordan's banking sector. Communications and Network, 9, 28-53.

Abualoush, S., Bataineh, K., \& Alrowwad, A. (2018a). The role of knowledge management process and intellectual capital as intermediary variables between knowledge management infrastructure and organization performance. Interdisciplinary Journal of Information, Knowledge, and Management, 13, 279-309.

Abualoush, S. H., Obeidat, A. M., Tarhini, A., Masa'deh, R., \& Al-Badi, A. (2018b). The role of employees' empowerment as an intermediary variable between knowledge management and information systems on employees' performance. VINE Journal of Information and Knowledge Management Systems, 48(2), 217-237.

Aguilera, R., Rupp, D., Williams, C., \& Ganapathi, J. (2007). Putting the S back in corporate social responsibility: A multilevel theory of social change in organizations. Academy of Management Review, 32(3), 836-863.

Al Azmi, N., Al-Lozi, M., Al-Zu’bi, Z., \& Dahiyat, S. (2012). Patients attitudes toward service quality and its impact on their satisfaction in physical therapy in KSA hospitals. European Journal of Social Sciences, 34(2), 300-314.

Al-dalahmeh, M., Khalaf, R., \& Obeidat, B. (2018). The effect of employee engagement on organizational performance via the mediating role of job satisfaction: The case of IT employees in Jordanian banking sector. Modern Applied Science, 12(6), 17-43.

Al-Dmour, R, Obeidat, B., \& Almajali, D. (2015). The practice of HRIS applications in business organizations in Jordan: An empirical study. 4th Scientific \& Research Conference on New Trends in Business, Management and Social Sciences (COES\&RJ-TK15/1).

Al-Dmour, R., Al Haj Dawood, E., Al-Dmour, H., \& Masa'deh, R. (2019). The effect of customer lifestyle patterns on the use of mobile banking applications in Jordan. Int. J. Electronic Marketing and Retailing, Forthcoming.

Aldmour, R., Masa'deh, R., \& Obeidat, B. (2017). Factors influencing the adoption and implementation of HRIS applications: Are they similar. International Journal of Business Innovation and Research, 14(2), 139-167.

Alenezi, H., Tarhini, A., Alalwan, A., \& Al-Qirim, N. (2017). Factors affecting the adoption of e-government in Kuwait: A qualitative study. Electronic Journal of e-Government, 15(2), 84-102.

AlHarrasi, J., \& AL-Lozi, M. (2015). The role of innovation management and technological innovation on organizational effectiveness. 4th Scientific \& Research Conference on New Trends in Business, Management and Social Sciences (COES\&RJ-TK15/1), Istanbul, Turkey.

AlHrassi, J., Al-Lozi, M., \& Irtaimeh, H. (2016). The impact of management innovation and technological innovation on organizational effectiveness: An empirical study from managerial staff perspective in Sultan Qaboos University. Journal of Social Sciences (COES\&RJ-JSS), 5(3), 309-339.

Alkandari, A., Masa'deh, R., \& Al-Lozi, M. (2017). Knowledge management and its role on organizational crisis management: A literature review. Journal of Social Sciences (COES\&RJ-JSS), 6(4), 833-850.

Almajali, D., \& Al-Dmour, R. (2016). The role of information technology in motivating students to accept e-learning adoption in universities: A case study in Jordanian universities. Journal of Business \& Management (COES\&RJ-JBM), 4(1), 36-46.

Almajali, D., \& Maqableh, M. (2015). Assessing the digital divide status of the Jordanian telecentre. International Journal of Communications, Network and System Sciences, 8(11), 428-439.

Almajali, D., Masa'deh, R., \& Al-Lozi, M. (2016). Determinants of the actual use of e-learning systems: An empirical study on Zarqa University in Jordan. Journal of Social Sciences (COES\&RJ-JSS), 5(2), 172-200.

AL-Syaidh, N., Al-Lozi, M., \& AlHarrasi, J. (2016). Transformational leadership and its role on the effectiveness of employees' behavior: A theoretical study. Journal of Business \& Management (COES\&RJ-JBM), 4(1), 14-35.

Ardakani, M., Zare, M., Mahdavi, S., Ghezavati, M., Fallah, H., Halvani, G., ... \& Bagheraat, A. (2013). Relation 
between job stress dimensions and job satisfaction in workers of a refinery control room. Journal of Community Health Research, 1(3), 198-208.

Bayley, D. H. (2015). Police and political development in India. Princeton University Press.

Calveras, A. (2013). External and internal corporate social responsibility: Complements through product quality. Evidence from the Hotel Industry. Retrieved December 2015, from http://www.webmeets.com/files/papers/earie/2013/339/CSR\%20and\%20product\%20quality\%20EARIE\%2 02013.pdf

Carlsson, J., \& Åkerstöm, R. (2008). Corporate social responsibility: A case study of Öhrlings Pricewaterhouse Coopers. Retrieved from http://www.diva-portal.org/smash/record.jsf?dswid=5456\&faces-redirect=true\&language=en\&searchType $=$ SIMPLE\&query $=\& \mathrm{af}=\% 5 \mathrm{~B} \% 5 \mathrm{D} \& \mathrm{aq}=05 \mathrm{~B} \% 5 \mathrm{~B} \% 5 \mathrm{D} \% 5 \mathrm{D} \& \mathrm{aq} 2=\% 5 \mathrm{~B} \% 5 \mathrm{~B} \% 5 \mathrm{D} \% 5 \mathrm{D} \& \mathrm{aqe}=\% 5 \mathrm{~B} \% 5 \mathrm{D} \& \mathrm{pi}$ $\mathrm{d}=$ diva2\%3A1031221\&noOfRows=50\&sortOrder=author_sort_asc\&sortOrder2=title_sort_asc\&onlyFullTe $\mathrm{xt}=$ false \&sf $=$ all

Cavazotte, F., \& Chang, N. C. (2016). Internal corporate social responsibility and performance: A study of publicly traded companies. BAR-Brazilian Administration Review, 13(4).

Darawsheh, S., ALshaar, A., \& AL-Lozi, M. (2016). The degree of heads of departments at the University of Dammam to practice transformational leadership style from the point of view of the faculty members. Journal of Social Sciences (COES\&RJ-JSS), 5(1), 56-79.

Elfenbein, D., Fisman, R., \& McManus, B. (2012). Charity as a substitute for reputation: Evidence from an online marketplace. Review of Economic Studies, 79(4), 1441-1468.

Grady, G., McCarthy, A., Darcy, C., \& Kirrane, M. (2008). Work-life balance policies \& initiatives in Irish organisations: A best practice management guide. Cork: Oak Tress Press.

Heslin, P. A., \& Ochoa, J. D. (2008). Understanding and developing strategic corporate social responsibility. Organizational Dynamics, 37(2), 125-144.

Jordanian Association of Pharmaceutical Manufacturers (2017). Retrieved from http://pharmaboardroom.com/pharmadirectory/the-jordanian-association-of-pharmaceutical-manufacturers/

Karajeh, H., \& Maqableh, M. (2014). Security of cloud computing environment. The 23rd IBIMA Conference on Vision 2020: Sustainable Growth, Economic Development, and Global Competitiveness, USA, 2202-2215.

Kateb, M., Swies, R., Obeidat, B., \& Maqableh, M. (2015). An investigation on the critical factors of information system implementation in Jordanian information technology companies. European Journal of Business and Management, 7(36), 11-28.

Khalayleh, W., Masa'deh, R., \& Al-Lozi, M. (2017). Administrative empowerment and its role on the work teams Performance: A literature review. Journal of Social Sciences (COES\&RJ-JSS), 6(4), 851-868.

Khwaldeh, S., Al-Hadid, I., Masa'deh, R., \& Alrowwad, A. (2017). The association between e-services web portals information quality and ICT competence in the Jordanian universities. Asian Social Science, 13(3), 156-169.

Maqableh, M., \& Karajeh, H. (2014). Job scheduling for cloud computing using neural networks. Communications and Network, 6(3), 191-200.

Maqableh, M., Rajab, L., Quteshat, W., Khatib, T., \& Karajeh, H. (2015). The impact of social media networks websites usage on students' academic performance. Communications and Network, 7(4), 159-171.

Masa'deh, R. (2016). The role of knowledge management infrastructure in enhancing job satisfaction at Aqaba five star hotels in Jordan. Communications and Network, 8(4), 219-240.

Masa'deh, R., Alrowwad, A., Alkhalafat, F., Obeidat, O., \& Abualoush, S. (2018). The role of corporate social responsibility in enhancing firm performance from the perspective of IT employees in Jordanian banking sector: The mediating effect of transformational leadership. Modern Applied Science, 12(7), 1-26.

Masa'deh, R., Gharaibeh, A., Maqableh, M., \& Karajeh, H. (2013a). An empirical study of antecedents and outcomes of knowledge sharing capability in Jordanian telecommunication firms: A structural equation modeling approach. Life Science Journal, 10(4), 2284-2296.

Masa'deh, R., Hunaiti, Z., \& Bani Yaseen, A. (2008). An integrative model linking IT-business strategic alignment and firm performance: The mediating role of pursuing innovation and knowledge management 
strategies. Communications of the International Business Information Management Association (IBIMA) Journal.

Masa'deh, R., Obeidat, B., Zyod, D., \& Gharaibeh, A. (2015). The associations among transformational leadership, transactional leadership, knowledge sharing, job performance, and firm performance: A theoretical model. Journal of Social Sciences (COES\&RJ-JSS), 4(2), 848-866.

Masa'deh, R., Shannak, R., \& Maqableh, M. (2013b). A structural equation modeling approach for determining antecedents and outcomes of students' attitude toward mobile commerce adoption. Life Science Journal, 10(4), 2321-2333.

Mikkawi, B., \& Al-Lozi, M. (2017). The impact of knowledge management infrastructure on academic staff effectiveness: An empirical study at The University of Jordan. Jordan Journal of Business Administration, $13(1), 95-127$.

Mory, L., Wirtz, B., \& Göttel, V. (2015). Factors of internal corporate social responsibility and the effect on organizational commitment. The International Journal of Human Resource Management, 27(13), 1393-1425.

Myers, R. (1990). Classical and modern regression with applications, PWS-KENT Publishing Co., Boston.

Nasrullah, N., \& Rahim, M. (2014). CSR in private enterprises in developing countries. Evidences from the ready-made garments industry in Bangladesh. Springer Publications, https://link.springer.com/book/10.1007\%2F978-3-319-02350-2

Obeidat, B., Hadidi, A., \& Tarhini, A. (2017). Factors affecting strategy implementation: A case study of pharmaceutical companies in the Middle East. Review of International Business and Strategy, 27(3), 386-408.

Obeidat, B., Tarhini, A., \& Aqqad, N. (2017). The impact of intellectual capital on innovation via the mediating role of knowledge management: A structural equation modeling approach. International Journal of Knowledge Management Studies, 8(3/4), 273-298.

Pallant, J. (2005). SPSS survival guide: A step by step guide to data analysis using SPSS for windows, 3rd Edition, Open University Press, New York.

Parvin, M., \& Nurul, K. (2011). Factors affecting employee job satisfaction of Pharmaceutical sector. Australian Journal of Business and Management Research, 1(9), 113-123.

Pietersz, G. (2011). Corporate social responsibility is more than just donating money. KPMG International, Curacao.

Santoso, I. L. (2014). The impact of internal CSR towards employee engagement and affective commitment in XYZ hotel Surabaya. Business Management, 2(2), 79-88.

Sekaran, U., \& Bougie, R. (2013). Research methods for business, 6th Edition. United Kingdom: John Wiley \& Sons Ltd.

Shannak, R., \& Obeidat, B. (2012). Culture and the implementation process of strategic decisions in Jordan. Journal of Management Research, 4(4), 257-281.

Shibeika, A. M. (2015). The impact of internal corporate social responsibility on job satisfaction within the banking sector in Sudan. Khartoum University Journal of Management Studies, 9(1), 65-87.

Spreitzer, G. M. (1995). Psychological empowerment in the workplace: Dimensions, measurement, and validation. Academy of Management Journal, 38(5), 1442-1465.

Suher, I. K., Bir, C. S., \& Yapar, A. (2017). The effect of corporate social responsibility on employee satisfaction and loyalty: A research on Turkish employees. International Research Journal of Interdisciplinary \& Multidisciplinary Studies (IRJIMS), 87-105.

Tamm, K., Eamets, R., \& Mõtsmees, P. (2010). Relationship between corporate social responsibility and job satisfaction: The case of Baltic countries. The university of Tartu faculty of economics and business administration working paper No. 76-2010.https://doi.org/10.2139/ssrn.1717710

Tarhini, A., Alalwan, A., Al-Qirim, N., \& Algharabat, R. (2018). An analysis of the factors influencing the adoption of online shopping. International Journal of Technology Diffusion (IJTD), 9(3), 68-87.

Tarhini, A., Al-Badi, A., Almajali, M., \& Alrabayaah, S. (2017a). Factors influencing employees' intention to use cloud computing. Journal of Management and Strategy, 8(2), 47. 
Tarhini, A., Al-Busaidi, K., Bany Mohammed, A., \& Maqableh, M. (2017b). Factors influencing students' adoption of e-learning: A structural equation modeling approach. Journal of International Education in Business, 10(2), 164-182.

Tarhini, A., Bany Mohammed, A., \& Maqableh, M. (2016). Modeling factors affecting student's usage behaviour of e-learning systems in Lebanon. International Journal of Business and Management, 11(2), 299.

Tarhini, A., Mgbemena, C., \& Trab, M. S. A. (2015). User adoption of online banking in Nigeria: A qualitative study. Journal of Internet Banking and Commerce, 20(3), 1-8.

Thang, N., \& Fassin, Y. (2017). The impact of internal corporate social responsibility on organizational commitment: Evidence from Vietnamese service firms. Journal of Asia-Pacific Business, 1-17.

Ugboro, I. O., \& Obeng, K. (2000). Top management leadership, employee empowerment, job satisfaction, and customer satisfaction in TQM organizations: An empirical study. Journal of Quality Management, 5(2), 247-272.

Yassien, E., \& Mufleh, M. (2017). The impact of ERP system's usability on enterprise resource planning project implementation success via the mediating role of user satisfaction. Journal of Management Research, $9(3)$, 49-71.

Yousaf, H. Q., Ali, I., Sajjad, A., \& Ilyas, M. (2016). Impact of internal corporate social responsibility on employee engagement a study of moderated mediation model. International Journal of Sciences: Basic and Applied Research (IJSBAR), 1-17.

\section{Copyrights}

Copyright for this article is retained by the author(s), with first publication rights granted to the journal.

This is an open-access article distributed under the terms and conditions of the Creative Commons Attribution license (http://creativecommons.org/licenses/by/4.0/). 